\title{
Reflections on Grundtvig and Germany
}

Reflections on Grundtvig and Germany in Connection with the New Grundtvig-edition in German

\section{By Theodor Jørgensen}

To speak of Grundtvig's relations with Germany is beset with difficulties, as we have Grundtvig's own statement that he would like to have as few of them as possible. In the first year of his periodical, Danskeren (The Dane), in 1848, he wrote that "Even though I have read more German and learned a smidgen of more languages than most cultivated Copenhageners do, I have nevertheless in the last $\mathbf{4 0}$ years spoken both so little and such bad German as has been possible; I have taught my children Danish above all things, and both as much and as well as I could, and I have always excused my considerable reading of German with the argument that one has to know that stuff in order to combat it; and I have offered the valid reason for all my dabbling with language that, as a world-historian, it was necessary for me; and I have always praised and elevated above all other things my Danish mothertongue and fatherland; and may it be so with all of us who really desire to fight for Denmark. (From G's article, "Den danske, den Tydske og den Franske Sag ; cf. US IX, pp. 110ff.; the quotation here is on p.120). The quotation derives from an article in which Grundtvig breaks with that submissiveness to German language and culture which, in his opinion, many contemporary Copenhageners demonstrated. Such behaviour weakens the Danish interest which, according to Grundtvig, consists in the fact that the Danish people, the Danish language and the Danish culture have value in their own right, a value which is not to be explained by something other than itself. Therefore he held that it is of decisive importance to have a living relationship to one's Danish mothertongue, and to cleanse oneself of all that muddy water which, in the form of foreign words, creeps into the language. The best defense of a people's specific character resides in its language, which is why Grundtvig was able to write 
the following lines in a poem which had appeared earlier in the year in the same periodical:

»Even though the German should behave ever so Spanish, do you only continue to speak Danish, that German not you into itself do banish.«

The picture which Grundtvig had of Germany at the time, and presumably also for the rest of his life, was the picture of an imperialistic state which sought to extend its borders as much as possible in both a literal and a figurative sense. To quote Grundtvig once again in the same article:

"Everyone who has ears can hear that the Germans are unlimited in their selfpraise and that, although God knows that we have praised them enough, they claim with address to us that he must praise himself who has evil neighbours, and everyone who has eyes can also see that the unlimitedness of the Germans does not reside in the cut of their clothes, but in the cut of their flesh; for this unlimitedness, which they themselves call exuberance (das Überschwengliche), is also seen in all their books and learned edifices, as well as in their claims on Schleswig, Bohemia, Posenia and, since they could not possibly confine themselves to the earth, on the whole of the invisible world into the bargain* (op.cit., p.128).

It would be hard to imagine that this imagery was plucked out of thin air. One might criticize Grundtvig for being onesided, and one might maintain that there was more to be said about Germany and German popular culture. However, it would be impossible to deny that the imperialistic aspect dominated for the rest of the century. One might reprove Grundtvig for assigning this feature to Germany in particular, when in fact it was common to all of the great European nations in the century of imperialism. However, Denmark happened to have a common border with Germany, and this made German imperialism especially tangible. But in addition to this, Grundtvig's stance was generally critical of imperialism, and he emphasized the world-historical missions of the smaller peoples by showing that 
it is possible for a people to derive its strength and its self-respect from other things than the naked exercise of power. But with respect to a border-trampling imperialism it is more essential to demarcate boundaries than to create relations, and this may be said to have characterized Grundtvig's relationship to Germany in general: that he demarcates both himself and Danishness so energetically that he, in his own words, "has acquired the reputation of harbouring and recommending an unexampled and awful hatred of all that is German «. (Danskeren, 1848 , p.350). Indeed, this caused him to write the article in Danskeren (»The Dane «) in 1848 bearing the superscription »The German-hatred of some others and myself « which I have just cited.

Grundtvig's hatred of the Germans is delimited in the following manner: »My hatred namely never pursues the Germans across the (river) Eider, so I am sincerely Eider-Danish, and my German hatred extends only to whatever is German to the extent that it or he may possibly injure Denmark « (ibid., p.351). But Grundtvig maintained that whatever else he critically wrote or uttered on the subject of Germany and German culture and spirituality he did mas an historical regarder-of-peoples... by no means because of hatred or envy, but for scholarly reasons, according to which canons my views may stand or fall« (ibid. ). According to Grundtvig, this hatred arises out of love of the fatherland, and thus out of love of humankind, of which true love of fatherland is only a nationally determined and coloured figure* (ibid. ). He juxtaposes this in opposition to another sort of German-hatred, one which would wish to storment and plague the Germans in their home (ibid., p.352), which would destroy Germany in every respect, its trade and shipping and hence all of its sources of nurture. Grundtvig says that such hatred struggles against brotherly love and could benefit no one, not even Denmark, »because trade is interconnected throughout the whole of Europex - Grundtvig was also quite pragmatic and held, moreover, that wsuch barbaric warfare would disgrace and corrupt the Danish people $\kappa$ (ibid.).

There is an equally expressive remark by Grundtvig as to the claim that he sought to devour all Germans from head to toe: $\bowtie I$ may assure you that in this respect $I$ am just as innocent as a 
child in its cradle, because, even if I were a cannibal, then the Germans would be the last thing I would eat, in part because they do not at all answer to my taste, but in particular because they are a people who have done much good for the world, and who most certainly will do more yet $«$. (quoted from Fl. Lundgreen-Nielsen, „Grundtvig og danskhed«, Dansk Identitetshistorie 3, p.84). Grundtvig's view of Germany was indeed complex!

One could formulate Grundtvig's view of Denmark's, and hence of his own, relationship to Germany in two sentences: 1 . Outwardly, it is necessary to set clear boundaries, both literally and spiritually; 2. inwardly, every type of German-ness is to be combatted. The latter, however, applies most of all to what Grundtvig called the »high- Germanic «, for the rights and affairs of both the low-German speakers in the dutchy of Schleswig and the Frisian speakers concerned him greatly.

This does not by any means signify that Grundtvig desired to exclude all influence from without on Denmark, including German influence. He was well aware that it was not only trade that was interconnected throughout Europe. But his point was invariably that foreign influences have to be adapted to a people's own premises in order to become a natural part of their lives. This presupposes that the national character knows and appreciates itself in the first place.

This emphasis on the necessity of Denmark's demarcation is also a feature of Grundtvig's understanding of Danish folk character and identity, as he in particular helped to define it. To him, Danishness was characterized by "Love, peacefulness, lack of desire for conquest, belief in God-given happiness, a modesty which may be replaced by courage and toughness when external provocations become too intense . (thus Fl. Lundgreen-Nielsen, op.cit., pp.78f.). If one who possesses such features of personality expects to survive, he must demarcate himself from his surroundings. Of course, Grundtvig was well aware that some of them could also evolve into lethargy and laziness, qualities for which he also criticizes the Dane. But there is no question but that Grundtvig was able to supply the sketch of a Danish identity which enabled Danes to survive the catastrophes in foreign politics of the 18th and 19th centuries. 
For Grundtvig, these specifically Danish characteristics were intimately linked with the coming into existence of the Danish people. Grundtvig emphasizes that the Danes are one of the oldest peoples in the world; they have always dwelled where they dwell at present, and they have had a continuous history under an unbroken series of kings. They did not conquer their country and thereby suppress others; nor are they marked by ambitions of conquest now. This close historically-conditioned stress on the land as the land which has always been one's own contributes to underline the demarcation in question.

This situation corresponds well with the idealized conception which Grundtvig made of Europe in one of his latest manuscripts, from 1865. Here he holds that evolution throughout the 19th century has been in the direction of a Europe of fatherlands. Now »Europe's map (must) be redrawn following the old ethnic-borders, and every people, great or small, must have peace and liberty on its own proper territory. This does not bode ill for Denmark and the High North, but, on the contrary, for the nations of war who have only lived by plundering and devouring small peoples«. (Grundtvig-Ark. Fasc. 204.3 b 66v; cited here following Fl. Lundgreen-Nielsen, op.cit., p.158). »Peace and freedom on its own proper territory « makes the demarcation essential, although not in an exclusive sense. Everyone who freely reckons himself to belong is welcome in a folk fellowship, under the presupposition of love for this people's mothertongue and involvement in the people's history (cf. Grundtvig's poem on »national character , 7th stanza). Grundtvig does not by any means rule out the reciprocal interactions of the nations, but he holds that they must be based on voluntariness and on respect for each other's borders and specific characters. What one appropriates from without must be appropriated in accordance with a people's spirit and nature. Grundtvig's deep aversion towards and suspicion of Germany was caused by the fact that he did not find German foreign policy to be characterized by such respect; rather, he understood Germany as the heir to the imperialism of the Roman empire, which, in Grundtvig's eyes, was the worst evil in the history of the world.

Grundtvig lived his own life conscious of this demarcation; he had no ambition for international fame. In a letter to his fellow 
poet B.S.Ingemann in 1843 he mentions that he has no room in his breast for anything but the great conception of a common rebirth of Danishness in the people (cf. Fl. Lundgreen-Nielsen, p.177). However, this is not an entirely candid self-description which Grundtvig offers of his own activity, since for Grundtvig the rebirth of Christian faith and the Christian church in Denmark was an equally decisive matter, one which, indeed, according to his understanding of the relationship between national character and Christianity, in fact presupposed the rebirth of Danishness. Grundtvig's stress on Danishness was not provincial, for it was far too historically, or, rather, world-historically founded for this to be possible. It is significant that Grundtvig never wrote a history of Denmark, but several world histories instead. This is important because ethnic self-understanding entails an understanding of the place and significance which one's own people has enjoyed in the context of world history.

It can hardly astonish us that God, according to Grundtvig, had assigned to the Danish people what was practically a soteriological role within world history. On this issue Grundtvig shared the religiously coloured concept of national election which was widespread in this epoch. One may rightly criticize him for this today, not least because of our acquired background of painful knowledge as to the consequences of any religiously founded nationalism. However, one ought also to note how Grundtvig regarded this special election. He found it to reside in the minuteness and vulnerability of the Danish people, in spite of which the people was able to go on, even after the great defeats and the continuing threats of the great powers - just as, once upon a time, the Israelite people became a witness to the fact that God is strong among the weak.

Grundtvig is Danish. It is unlikely that there was ever another Dane who loved Danishness as intensely as Grundtvig did. This is above all evident in his relationship to the Danish language. His heart literally resounds to the cadences of his mothertongue, to paraphrase one of his poems (cf. «Moders Navn er en himmelsk Lyd ). This applies not only to the sound of the language, but also to Grundtvig's use of expressions, aphorisms, proverbs and metaphors. His emphasis on the importance of the living word, that is, on speech, in contradistinction to the dead word, 
that is, the dead letter, is also reflected in his use of the language: either poetically, so that it may be sung, or in speech cadences, even if it is destined to be printed. Grundtvig's prose is very much orally based.

Grundtvig was a Christian. He was a pastor, a theologian, a reformer, or, at least, this is how he understood himself: as an heir of M.Luther, as a renewer of Luther's reformation in the north. This brings another aspect of Grundtvig's relationship to Germany into the picture. For Grundtvig, there was no opposition between his Danishness and his Christianity. Quite the contrary, in fact: throughout his entire life Grundtvig advocated the congenial reciprocity of national character and Christianity: «National character is the greatest and most powerful revelation to human life on this side of the Day of Judgement, so that even the most pure and Christian humanity can only manifest itself as congregational life in national form «. (Fasc. $20317 \mathrm{r}$; cited here following Fl. Lundgreen-Nielsen, op.cit., p.152). And he had no doubt whatever that the specifically Danish national character had a special affinity for Christianity. Therefore Grundtvig perceived no contradiction between his calling as an awakener of the people and his calling as a reformer of the church. In reality, these were two sides of the same coin.

Nevertheless, Grundtvig's calling as a Christian reformer was the more important to him. The people or congregation of God was much, much more than the Danish people. Even though he wavered on the issue on occasion, Grundtvig mainly held that no people, no specific national character could enjoy any qualitative pre-eminence with respect to Christianity. He wished to make a clear distinction on this point, and, as far as I can see, this is the reason why the national feeling which Grundtvig shared with other 19th-century figures, also as far as religious colouration is concerned, did not generally evolve into nationalism, even if we may note occasional lapses from grace in this respect. Grundtvig's universal-historical understanding of existence was conditioned by his Christianity; it militated against any exclusive ethnocentrism, and his clear awareness that the kingdom of God was other and more than people and patria ensured that his love of fatherland did not assume religious character. Although Grundtvig regarded Danishness as that national character which 
was most congenial to Christianity, it could nevertheless not become anything but a guestroom for Christianity.

I have attempted here to offer a brief description of Grundtvig's understanding of the relationship between Danish national character and Christianity, and of Germany and the German national character. I have done this in order to stress the problems involved in translating Grundtvig into German. How can it be done at all? And, moreover, if one were to do it, would one not then be confronted by insurmountable difficulties of translation, not to mention those difficulties which would arise for the Germans' reception of Grundtvig?

Why should one translate Grundtvig at all, since he is so Danish, and since his understanding of Christianity is so preoccupied with the reciprocal relationship between Christianity and Danishness? And, moreover, when Grundtvig himself did not wish to be active beyond the borders of Denmark? Why should we translate Grundtvig when, not least in his capacity as a poet, but certainly also in his prose style, he is so difficult in his use of the Danish language that he truly offers every translator enormous difficulties?

This has also been the predominant attitude in Denmark for many years. A few of Grundtvig's writings have been translated, particularly the pedagogical ones, and they have in fact been extensively treated on the initiative of non-Danish scholars. But otherwise, most people have deferred to the view that Grundtvig was so specifically Danish that any translation of him to some other language would necessarily lead to misunderstandings. Also, people have, with a certain amount of justification, held that the initiative for a more extensive translation project ought to come from without. If scholars in the English- or German-speaking communities really desired such a translation, they would no doubt find ways to realize the project.

This view has much to commend it. One has merely to point to Grundtvig's two famous contemporaries in Copenhagen, Søren Kierkegaard and Hans Christian Andersen. It has not proved necessary in either case for Danes to take the lead to ensure their translation into the main world languages. This has happened as a matter of course as a result of the influence which they exercised through their writings on Danish-speaking 
foreigners, who acted on their behalf. Nevertheless, this view is too limited, in particular because we have to do with translation from so restricted a linguistic region as the Danish one. The initiative must necessarily often come from the Danish side, especially when we have to do with an author whose writings are as idiosyncratic as Grundtvig's.

In addition to this, every people has a moral obligation to render itself intelligible to others, above all in a time in which living with one another in a reciprocally demanding community is an essential challenge, if humanity is to survive. This is, in brief, the perspective which this conference intends to develop. And if Denmark and the Danish national character are to be made intelligible to others, then the dissemination of greater knowledge of Grundtvig is essential. As far as I am aware, the history of the European nations does not offer a corresponding example of how a single individual has managed to put his stamp on the entire life of his country as Grundtvig did in Denmark in conjunction with school and church, political life, organizations, leisure-time pursuits, and so forth. Many features of contemporary Denmark still bear Grundtvig's fingerprints, even though people may be only dimly aware of his name. It is not least all the many national folk high-schools, which are further developments of Grundtvig's ideas about enlightenment of the people, which have brought this about. If an outsider is to have a chance to arrive at a deep and thorough knowledge of Danish culture and national life, he must have the possibility to immerse himself in the many facets of Grundtvig's writings. This makes it morally incumbent on us in Denmark to publish a representative segment of Grundtvig's publications in at least one, and preferably in more than one, of the major world languages.

The German-language edition of Grundtvig which is being produced so assiduously at present is concerned to offer such a representative selection. It has been planned to extend to three volumes of about 350 pages each. One volume contains a selection of Grundtvig's philosophical, poetic and historical writings, another a selection of his pedagogical and political writings, while the third contains a sample of theological texts, that is, treatises, sermons and hymns. On the whole the edition aims to present some of Grundtvig's poetry, no matter what 
translational problems might be attendant on this. Another principle of selection has been to present as many whole texts as possible, since every abridgment is by the same token also an interpretation. This is naturally also true of a selection as a whole. Therefore, in order to avoid any potential one-sidedness the editors have chosen to allow the entire group of about 25 co-workers to participate in evaluating and commenting on the type and nature of the selections, as well as to suggest possible alternatives.

But why did we choose to concentrate on German as the first main language for a translation of a representative selection of Grundtvig-texts? Why did we not choose English, which, after all, as a world language covers the interests of a far larger portion of the world? As is inevitably the case, the reason has partially to do with the personal presuppositions of the organizational group. I myself grew up on the German-Danish border under the influence of the cultural encounter and cultural struggle there, where the mothertongues are Danish, German and South-Jutlandic. Of course, the border-fellowship which Denmark shares with Germany, plus the existence of national minorities both north and south of the border, entail an especial obligation to cultural intermediation across the border, particularly now, after the formation of the European community.

Furthermore, a border-fellowship is also always synonymous with an especially intense historical fellowship. This has truly been the case with the Danish-German border-fellowship as long as it has existed, with its border which has moved first one way and then another. Such things leave traces which are often enough painful ones; they create robustly enduring prejudices and deep reservations on both sides. As we have seen, Grundtvig himself is an example of such reservations and prejudices with respect to Germanness. But for the sake of ethnic coexistence such reservations and prejudices must be overcome. This can only happen if we learn to understand each other better from within, and not least by critical exposure of both reservations and prejudices we will become aware of what has caused them. Not all prejudices or reservations are unmotivated. A critically understanding approach to other peoples' prejudices and reservations concerning one's own people can lead to fruit- 
ful and much-needed self-criticism. Being a child of the 19th century, and possessing such great love of Danishness, Grundtvig bore the stigmata of the Danish-German conflict. Anything else would be quite remarkable. But for this very reason it may be that a presentation of his authorship in German might contribute to advancing the necessary critical exposure of prejudices and reservations on both sides.

Germans harbour both great reservations and bitter prejudices in particular with respect to Grundtvig's emphasis on the importance of national character in itself and also in its reciprocity with Christianity. For Germans who experienced the nightmare of Hitler, but also for the younger generation which has grown up in intense opposition to the days of Hitler, Grundtvig's talk about the necessity to love one's people and one's fatherland is like a firebrand in the throat. One would rather be a European or a citizen of the world than a German. One might be, in a pinch, a Bavarian, a Rhinelander, a Schleswig-Holsteiner, or a Hanseatic, but not a German. And a German's rejection and dismissal become even greater when he is told that love of people and fatherland is a presupposition of the first order for being able to understand the Gospel about the kingdom of God; or that intimacy with Norse mythology can provide a key for the understanding of Christianity. Children who play with fire burn their fingers; to German sensibilities it all smells entirely too much of that phenomenon of Hitler's day, the "German Christians«, some of whom did in fact actually cite Grundtvig's authority.

Now these are extremely understandable reservations and prejudices, and Danes would be ill-advised to ignore the critical warnings contained in them. At the present time in Europe it is once again the case that the symbiosis between nationality and confession or religion assumes an extremely problematical role. And the tormented history of Europe throughout the 19th and 20th centuries is intimately connected with the religious legitimation of national imperialism. After all, we all fought »with

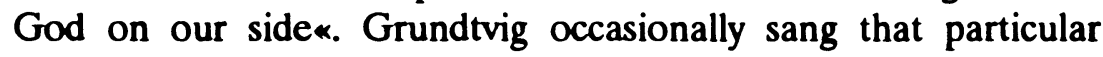
tune himself; but it was his and Denmark's good fortune that it happened at a time when Denmark had lost all semblance of mi- 
litary strength and thus could not have succumbed to the implicit temptation.

On the other hand, the Germans' understandable prejudices and reservations are also an expression of the on-going German attempt to repress the problem of German identity in contemporary German society, a factor which has been conditioned to a large extent by the long-standing partition of Germany. But the attempt to repress the question of German identity may well prove to be extremely dangerous in the long run, as in a given situation it may once again erupt and explode in a rightwing wave of German nationalistic extremism. Without wishing in any y to underestimate the importance of the political, economic and social problems which have accompanied the reunification of the two Germanies it is nevertheless appropriate to enquire as to whether it is not precisely the unsolved question of German identity which, seen in a higher perspective, is one of the most profound causes of the difficulties.

It is the opinion of the editors that a German-language edition of Grundtvig may not only be useful for Germans who attempt to arrive at a more richly differentiated and hence more just picture of Grundtvig's thoughts about national character and about the relationship between national character and Christianity, and thus also of the Danish self-understanding today. A German version of Grundtvig might hopefully also be able to supply a fruitful contribution to German self-enquiry and debate about the nature of German identity or national character. And it might possibly prompt German theology once again to deal with a topic which has been practically speaking tabu ever since the "confessing church $\ll$ distanced itself from »German Christianity<: the relationship between national character and Christianity. If only a few of the extremely troublesome considerations about such concepts as »people«, »national character «, "fatherland $\star$ and mothertongue $*$ which we pondered in the course of the translation should happen to repeat themselves for the future German reader, this would be fruitful for the German debate.

Grundtvig's ideas about schools and high-schools, which are probably that part of his authorship which has won the broadest hearing for itself in Germany, and probably more in Germany 
than elsewhere in Europe, with the exception of Scandinavia, are closely allied to this entire question of national self-understanding. Now Grundtvig's school and high-school ideas have often been dealt with in independence from the rest of his authorship. Unhappily, it is precisely there that the interaction between Grundtvig's political activity and his related political writings is important. But no less important is the interaction between Grundtvig's historical works and, last but not least, his theological writings. The concept of »life-enlightenment « is central to Grundtvig's pedagogical writings; in spite of Grundtvig's deep rootedness in 19th century romanticism, he also remained throughout his life an heir to the best of the Enlightenment. However, Grundtvig found the real basis for what he understood by »life-enlightenment « in v.4 of the prologue to the Gospel of John, in the form of the Word which was with God from the beginning and which was God: "In him was life, and life was the light of man «.

With the German-language edition of Grundtvig we are attempting to provide access to the various sides of Grundtvig's writings, and not least to his school and high-school ideas with all their internal connexions, and with the theological foundation which is characteristic for all of them, including where it is not expressed. The last-mentioned feature was also a motive for stressing the need to translate Grundtvig into German.

The churches in the German-language regions belong to a considerable extent to the Lutheran confession. As we have seen, Grundtvig understood his efforts to correspond to those of Luther and the Reformation in general, only in the context of the 19th century. Here in Denmark our understanding of the meaning of the Lutheran tradition has been unmistakably influenced by Grundtvig's transmission of it. An integration of the Reformatory impulse with that which characterizes our time, namely the aspects of individual culture, view of history and cultural self-consciousness, has taken place. Liberal theology attempted the same thing, but it abandoned the substance of the Reformation, which Grundtvig never did. Scholars have with reason called Luther one of the most influential church-teachers of the 20th century. This is appropriate because we have had access in this century to Luther's writings and thought as never before. 
It is precisely in this connexion that Grundtvig's original appropriation of Luther's theological mission and his contemporary integration of it are of importance for Lutheran theology and ecclesiastical life elsewhere. This might help to prevent the present interest in Luther from developing into a variety of Lutheran orthodoxy, as there seem to be such tendencies in the German-language area. And Grundtvig's theology may be able to open up the possibility for a renewed discussion of the relationships between Christianity and culture and Christianity and national character which has long been repressed.

But what I have said up to this point could at most be reformulated so as to provide good arguments for a larger and more representative translation of selected writings by Grundtvig into English. It could well be that the selection might not be completely identical with the German one, but the editors hope that we have at least completed a pilot project on which others can build further. In his understanding of Christianity, Grundtvig was ecumenical, for which reason he was also, as an historian, a universal historian. And it is precisely Grundtvig's understanding of the importance of national character for understanding how the Word of God really becomes flesh and takes up its abode among people which also makes his theological approach relevant to all attempts to write contextual theology and the inculturation of the Gospel. It is likewise significant that Third World theologians who have encountered Grundtvig understand him as providing inspiration for windigenous theology $\ll$. Similarly, teachers in the Third World understand Grundtvig on the basis of his ideas about schools and highschools. All of this suggests the need for a more extensive edition of Grundtvig in English; and with this wish, I now close. 